\title{
Ziyuglycoside II-induced apoptosis in human gastric carcinoma BGC-823 cells by regulating Bax/Bcl-2 expression and activating caspase-3 pathway
}

\author{
A.K. Zhu ${ }^{1}$, H. Zhou ${ }^{2}$, J.Z. Xia ${ }^{2}$, H.C. Jin ${ }^{1}$, K. Wang ${ }^{3}$, J. Yan ${ }^{2}$, J.B. Zuo ${ }^{2}$, X. Zhu ${ }^{3}$ and T. Shan ${ }^{2}$ \\ ${ }^{1}$ Department of General Surgery, Nanjing Medical University, Affiliated Hangzhou Hospital, Hangzhou, China \\ ${ }^{2}$ Department of General Surgery, Nanjing Medical University, Affiliated Wuxi Second Hospital, Wuxi, China \\ ${ }^{3}$ Key Laboratory of Nuclear Medicine, Ministry of Health, Jiangsu Key Laboratory of Molecular Nuclear Medicine, \\ Jiangsu Institute of Nuclear Medicine, Wuxi, Jiangsu Province, China
}

\begin{abstract}
Ziyuglycoside II is an active compound of Sanguisorba officinalis L. that has anti-inflammation, antioxidation, antibiosis, and homeostasis properties. We report here on the anticancer effect of ziyuglycoside II on human gastric carcinoma BGC-823 cells. We investigated the effects of ziyuglycoside II on cell growth, cell cycle, and cell apoptosis of this cell line. Our results revealed that ziyuglycoside II could inhibit the proliferation of BGC-823 cells by inducing apoptosis but not cell cycle arrest, which was associated with regulation of $\mathrm{Bax} / \mathrm{Bcl}-2$ expression, and activation of the caspase- 3 pathway. Our study is the first to report the antitumor potential of ziyuglycoside II in BGC-823 gastric cancer cells. Ziyuglycoside II may become a potential therapeutic agent against gastric cancer in the future.
\end{abstract}

Key words: Ziyuglycoside II; BGC-823 cells; Apoptosis; Bax/Bcl-2; Caspase-3

\section{Introduction}

Gastric cancer is the second most common cancer in the world. It causes about 800,000 deaths each year, over $70 \%$ of which are in developing countries (1-3). Currently, gastric cancer is only treated with surgery or radiation therapy, followed by chemotherapy (4). The outcome of chemotherapy is often unsatisfactory primarily due to development of multiple drug resistance, which results in recurrent carcinoma of the stomach $(5,6)$. Therefore, research to develop more effective pharmaceutical agents against gastric cancer is ongoing.

In recent decades, compounds isolated from traditional Chinese herbs have been recognized as a most valuable resource in the development of novel and advanced cancer therapies (7-9). The dried root of Sanguisorba officinalis L., a plant that is widely distributed throughout China, Japan, and Korea, has been used to treat inflammatory and metabolic diseases for centuries $(10,11)$. Recently, compounds exacted from this plant have been reported to exhibit anticancer activity (12-14). Ziyuglycoside II (Figure 1) is one of the major active compounds of $S$. officinalis $\mathrm{L}$. and has various clinical effects including hemostasis, antibiosis, diminishing inflammation, and antioxidation (15). However, no previous studies have evaluated its anticancer activity.

In this study, the anticancer effect of ziyuglycoside II on the human gastric cancer cell line BGC-823 was investigated for the first time. The underlying molecular mechanisms of its effects on cell proliferation, cell cycle phases, and apoptosis were explored in BGC-823 cells treated with ziyuglycoside II.

\section{Material and Methods}

\section{Chemicals and reagents}

Ziyuglycoside II (purity $\geqslant 99 \%, M W: 604.8$ ) and 5-fluorouracil (purity $\geqslant 99 \%, M W: 130.1$ ) were obtained from the National Institute for the Control of Pharmaceutical and Biological Products (Beijing, China). RPMI 1640 culture medium, penicillin-streptomycin, trypsin, and fetal bovine serum (FBS) were obtained from Gibco (USA).

Correspondence: J.Z. Xia, Department of General Surgery, Nanjing Medical University, Affiliated Wuxi Second Hospital, No. 68 ZhongShan Road of Wuxi, Wuxi 214002, Jiangsu Province, China. E-mail: jzxia99@gmail.com 


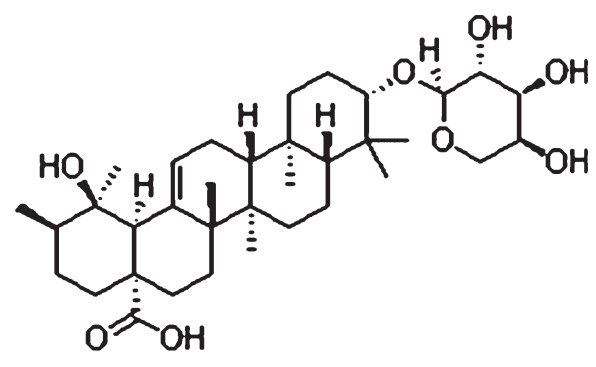

Figure 1. Chemical structure of ziyuglycoside II.

MTT [3-(4,5-dimethylthiazol-2-yl)-2,5-diphenyl tetrazolium bromide], dimethyl sulfoxide (DMSO), sodium bicarbonate, propidium iodide (PI), PVDF membranes, and an enhanced chemiluminescence (ECL) detection kit were obtained from Beyotime (China). Annexin V-FITC and PI double-staining kits were obtained from Pharmingen (USA), and ApoAlert cell fractionation kits were obtained from Clontech (USA). Antibodies against Bax, Bcl-2, $\beta$-actin, and HRP-conjugated rabbit anti-mouse secondary antibody were obtained from Santa Cruz Biotechnology (USA). z-Tyr-Val-Ala-Asp-fluoromethylketone (z-YVADfmk), z-Asp-Glu-Val-Asp-fluoromethylketone (z-DEVD$\mathrm{fmk}$ ), z-lle-Glu-Thr-Asp-fluoromethylketone (z-IETD-fmk), z-Leu-Glu(OMe)-His-Asp(OMe)-fluoromethylketone (z-LEHD-fmk), and caspase-3 fluorimetric assay kits were obtained from BioVision (USA).

\section{Cell culture}

Human gastric carcinoma BGC-823 and the CTLL-2 mouse cytotoxic T-cell lines were obtained from the American Tissue Culture Collection. BGC-823 cells were cultured in RPMI 1640 medium supplemented with 10\% FBS and $1 \%$ penicillin-streptomycin; CTLL-2 cells were maintained in RPMI 1640 containing 10\% FBS, 1\% penicillin-streptomycin, and $50 \mathrm{U} / \mathrm{mL} \mathrm{IL-2}$ at $37^{\circ} \mathrm{C}$ in a humidified atmosphere containing $5 \% \mathrm{CO}_{2}$.

\section{Cell growth assay}

The inhibition of cell growth was determined by MTT assay. Cells were seeded on 96-well culture plates $\left(2 \times 10^{4}\right.$ cells/well) with RPMI 1640 containing 10\% FBS. After $24 \mathrm{~h}$ of incubation, cells were treated with various concentrations of ziyuglycoside II or 5-fluorouracil. Following incubation, cell growth was measured at different time points with the addition of $20 \mu \mathrm{L}$ MTT followed by incubation for $4 \mathrm{~h}$ at $37^{\circ} \mathrm{C}$. Then, $150 \mu \mathrm{L}$ DMSO was added to dissolve the formazan crystals. Absorbance (A) was measured at $570 \mathrm{~nm}$ with an ELISA plate reader (Dynex, USA). Cell viability was expressed as a percent of the control. The experiments were done in triplicate and the results are reported as means of three independent measurements.

\section{Cell cycle and apoptosis analysis}

The cell cycle distribution and cell apoptosis were examined by flow cytometry (Becton Dickinson FacsCalibur, USA). Cells were seeded on 6-well plates $\left(5 \times 10^{5}\right.$ cells/well $)$ and treated with various concentrations of ziyuglycoside II for $24 \mathrm{~h}$. After treatment, cells were washed twice with ice-cold phosphate-buffered saline (PBS) and then centrifuged. The pellet was fixed in $75 \%$ $(\mathrm{v} / \mathrm{v})$ ethanol for $1 \mathrm{~h}$ at $4^{\circ} \mathrm{C}$, washed once with ice-cold PBS, and then suspended in cold PI solution $(50 \mu \mathrm{g} / \mathrm{mL})$ containing RNase $A(0.1 \mathrm{mg} / \mathrm{mL})$ in PBS, $\mathrm{pH} 7.4$, for $30 \mathrm{~min}$ in the dark. The cell suspension was then passed through a 35- $\mu \mathrm{m}$ mesh filter and analyzed by flow cytometry. In addition, cells were washed twice with icecold PBS and resuspended in $300 \mu \mathrm{L}$ binding buffer (Annexin V-FITC kit) containing $10 \mu \mathrm{L}$ Annexin V-FITC stock and $10 \mu \mathrm{L} \mathrm{Pl}$. After incubation for $15 \mathrm{~min}$ at room temperature in the dark, the samples were analyzed by the CELLQuest software (BD Biosciences, USA) for the evaluation of cell apoptosis.

\section{Western blot analysis}

Whole cells were lysed in lysis buffer [ $1 \%$ Triton $\mathrm{X}-100,0.5 \%$ sodium deoxycholate, $0.1 \%$ sodium dodecyl sulfate (SDS), $1 \mathrm{mM}$ phenylmethanesulfonyl fluoride (PMSF), $1 \mathrm{mM}$ DL-dithiothreitol (DTT), $10 \mu \mathrm{g} / \mathrm{mL}$ aprotinin, $10 \mu \mathrm{g} / \mathrm{mL}$ leupeptin, $1 \mathrm{mM}$ sodium orthovanadate in PBS, pH 7.4], for $30 \mathrm{~min}$ and then centrifuged at 16,000 $\mathrm{g}$ for $30 \mathrm{~min}$ at $4^{\circ} \mathrm{C}$. The cytosol fraction and mitochondrial fraction were prepared using an ApoAlert cell fractionation kit. The protein concentration of samples was determined with the Bradford method. Then, the samples $(50 \mu \mathrm{g})$ were applied to $10 \%$ SDS polyacrylamide gel and transblotted onto PVDF membranes. After blocking with $5 \%$ BSA in Tris-buffered saline (TBST) for $1 \mathrm{~h}$, membranes were incubated with the primary antibodies against $\mathrm{Bax}, \mathrm{Bcl}-2$, and $\beta$-actin overnight, and followed by secondary antibody incubation for $1 \mathrm{~h}$ at room temperature. Protein bands were visualized with the ECL detection kit. The density of each band was normalized against $\beta$-actin.

\section{Fluorimetric assay for caspase-3 activity}

The caspase- 3 fluorimetric assay measured its activity by detecting cleavage of its substrate DEVD-AFC. BGC823 cells $\left(2 \times 10^{6}\right.$ cells) were collected and lysed in caspase assay buffer containing $50 \mathrm{mM}$ 2-[4-(2-hydroxyethyl)-1piperazinyl]ethanesulfonic acid (HEPES), $\mathrm{pH} 7.5,100 \mathrm{mM}$ $\mathrm{NaCl}, 2 \mathrm{mM}$ ethylene diamine tetraacetic acid (EDTA), $0.1 \% 3-[(3-c h o l a m i d o p r o p y l) d i m e t h y l a m m o n i u m]-1-p r o-$ panesulfonate (CHAPS), $10 \%$ sucrose and $5 \mathrm{mM}$ DTT. Aliquots of crude cell lysate $(100 \mu \mathrm{L})$ were incubated with caspase- 3 substrate DEVD-AFC at $37^{\circ} \mathrm{C}$ for $30 \mathrm{~min}$. The caspase- 3 activity was quantified by a spectrofluorometer with an excitation wavelength at $400 \mathrm{~nm}$ and an emission wavelength at $505 \mathrm{~nm}$. 


\section{Statistical analysis}

Biostatistical analyses were conducted with Prism 5.0 and SPSS 16.0 software packages. All experiments were repeated three times. Results of multiple experiments are reported as means $\pm S D$. A $P$ value less than 0.05 was accepted as statistically significant.

\section{Results}

\section{Inhibitory effect of ziyuglycoside II on BGC-823 cell} growth

We first determined the inhibitory effect of ziyuglycoside II on BGC-823 cell growth at 24 and 48 h by MTT assay. As shown in Figure 2A, ziyuglycoside II exhibited a remarkably strong inhibitory effect on the growth of BGC-823 cells, which was similar to that of 5-fluorouracil, a clinically used drug (Figure 2B). The $\mathrm{IC}_{50}$ of ziyuglycoside II at 24 and $48 \mathrm{~h}$ was 14.40 and $10.11 \mu \mathrm{M}$, respectively. In addition, ziyuglycoside II showed low cytotoxicity in the murine cytotoxic T-cell line CTLL-2 (Figure 2C).

\section{Effects of ziyuglycoside II on BGC-823 cell cycle and apoptosis}

To further examine the molecular mechanism of ziyuglycoside II-mediated cell growth inhibition in BGC823 cells, cell cycle distribution and apoptosis were evaluated by flow cytometry. Compared with controls, there was no appreciable cell cycle arrest after $24 \mathrm{~h}$ of ziyuglycoside II treatment (Table 1). The effect of ziyuglycoside II on BGC-823 cell apoptosis was assessed by the Annexin V-PI dual-staining assay. Our results showed that the apoptotic rate was significantly increased by ziyuglycoside II treatment at $5 \mu \mathrm{M}(28.17 \pm 3.15 \%$, $\mathrm{P}<0.05), \quad 10 \mu \mathrm{M}(40.12 \pm 6.27 \%, \mathrm{P}<0.05)$, and $25 \mu \mathrm{M}$ $(62.34 \pm 10.13 \%, P<0.05)$ for $24 \mathrm{~h}$ in comparison with controls (0.05 $\pm 0.03 \%$; Figure 3$)$.

\section{Effect of ziyuglycoside II on expressions of Bax and $\mathrm{Bcl}-2$ proteins}

The $\mathrm{Bcl}-2$ family plays an essential role in the regulation of apoptosis (16). To confirm whether such a mechanism is involved in ziyuglycoside II-induced apoptosis of BGC-823 cells, the expressions of $\mathrm{Bax}$ and $\mathrm{Bcl}-2$ were evaluated. After normalization, the expression of $\mathrm{Bcl}-2$ was downregulated following ziyuglycoside II (5 to $25 \mu \mathrm{M})$ treatment for $24 \mathrm{~h}$. In contrast, Bax expression was upregulated under the same conditions (Figure 4A). The Bax/Bcl-2 ratio increased in a dose-dependent manner compared to the control (Figure 4B). Furthermore, cytosol and mitochondrial preparations of the whole cell population (including apoptotic and nonapoptotic cells) showed clearly that redistribution of Bax (from the cytosol to mitochondria) was induced by ziyuglycoside II in this cell line (Figure 4C and $\mathrm{D}$ ). These observations suggest that the Bcl-2 family, including Bax and $\mathrm{Bcl}-2$ proteins, plays an important role in ziyuglycoside II-induced cell apoptosis.
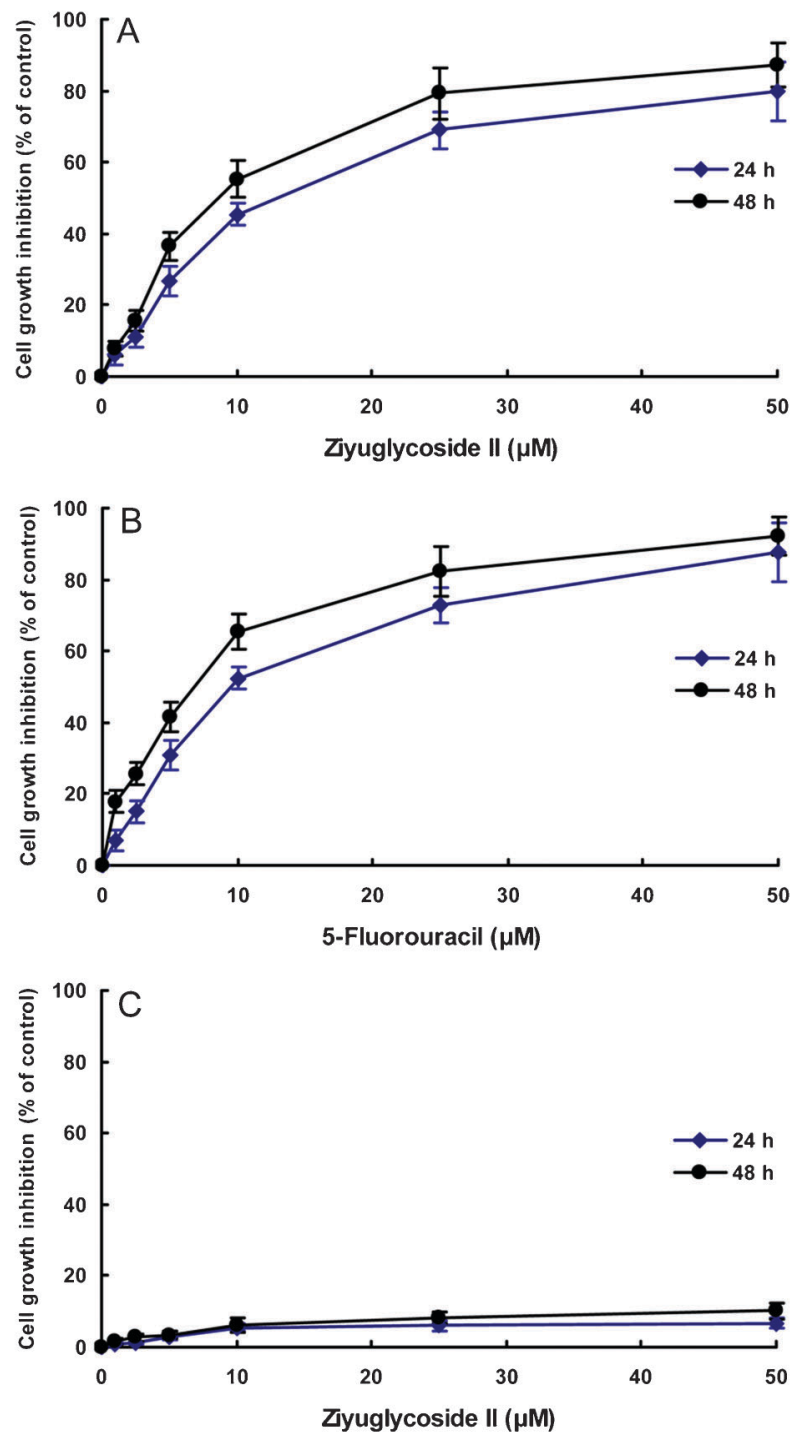

Figure 2. Inhibitory effect of ziyuglycoside II and 5-fluorouracil on the proliferation of BGC-823 or CTLL-2 cells determined by MTT assay. $A$, Inhibition of BGC-823 cell growth after treatment with ziyuglycoside II. B, Inhibition of BGC-823 cell growth after treatment with 5-fluorouracil. $C$, Inhibition of CTLL-2 cell growth after treatment with ziyuglycoside II. Data are reported as means $\pm S D$ percent of cell proliferation relative to the proliferation of controls $(n=3)$.

\section{Effects of caspase-3 pathway activation on ziyuglycoside II-induced apoptosis}

To assess whether the caspase pathway is involved in the ziyuglycoside II-induced apoptosis of BGC-823 cells, three caspase inhibitors were applied. Cells were pretreated with caspase-1 inhibitor (z-YVAD-fmk), caspase-3 inhibitor (z-DEVD-fmk), caspase-8 inhibitor (z-IETD-fmk), and $20 \mu \mathrm{M}$ caspase-9 inhibitor (z-LEHD-fmk) for $1 \mathrm{~h}$ and then cultured with $25 \mu \mathrm{M}$ ziyuglycoside II for $12 \mathrm{~h}$. When 
Table 1. Effect of ziyuglycoside II on cell cycle distribution of BGC-823 cells after a $24-\mathrm{h}$ treatment.

\begin{tabular}{lccc}
\hline $\begin{array}{l}\text { Concentration } \\
(\mu \mathrm{M})\end{array}$ & \multicolumn{4}{c}{ Cell cycle $(\%)$} \\
\cline { 2 - 4 } & $\mathrm{G}_{0} / \mathrm{G}_{1}$ & $\mathrm{~S}$ & $\mathrm{G}_{2} / \mathrm{M}$ \\
\hline 0 (control) & $59.30 \pm 1.35$ & $16.88 \pm 2.03$ & $21.99 \pm 0.73$ \\
5 & $56.79 \pm 2.26$ & $18.32 \pm 0.89$ & $19.53 \pm 0.58$ \\
10 & $57.52 \pm 1.11$ & $16.59 \pm 0.96$ & $20.12 \pm 1.38$ \\
25 & $58.39 \pm 1.19$ & $15.09 \pm 1.24$ & $20.02 \pm 2.17$ \\
\hline
\end{tabular}

BGC-823 cells were pretreated with z-DEVD-fmk, the ziyuglycoside II-induced loss of cell viability was markedly reduced from $75.37 \pm 3.81$ to $15.24 \pm 2.62 \%$, while z-YVAD-fmk, z-IETD-fmk, and z-LEHD-fmk only partly inhibited ziyuglycoside Il-induced cell death (Figure 5). A fluorimetric assay was used to measure cleavage of the caspase-3-specific fluorogenic substrate (DEVD-AFC), with the results considered to indicate caspase- 3 activity. Ziyuglycoside II increased caspase-3 activity in a dosedependent manner. The addition of the specific caspase-3 inhibitor (z-DEVD-fmk, $20 \mu \mathrm{M}$ ) reduced ziyuglycoside II-induced caspase-3 activity (Figure 6). In view of these results, we concluded that activation of the caspase-3 pathway plays an important role in ziyuglycoside II-induced apoptosis of BGC-823 cells.

\section{Discussion}

Natural compounds extracted from Chinese herbs are a valuable resource for chemoprevention and chemotherapeutic agent development (17). S. officinalis L. is one of the popular traditional Chinese medicines used in the treatment of inflammation and metabolic diseases and various cancers (10-14). Previous studies have reported that the ethanol and methanol extracts of $S$. officinalis $L$. exhibit anticancer activity in vitro (12). Ziyuglycoside II is one of the major active compounds of $S$. officinalis $L$., but it has never been evaluated for its anticancer effect. The current study was the first to investigate the molecular effects of ziyuglycoside II on BGC-823 gastric cancer cells. Our data demonstrated that ziyuglycoside II significantly inhibited the growth of BGC-823 gastric cancer cells in a dose- and time-dependent manner. The $I_{50}$ effect was $14.40 \mu \mathrm{M}$ at $24 \mathrm{~h}$ and $10.11 \mu \mathrm{M}$ at $48 \mathrm{~h}$. Flow cytometry indicated that the suppressive effect of ziyuglycoside II on cell growth was not mediated by arresting the cell cycle but by inducing apoptosis of BGC-823 cells.

The results also elucidate the molecular mechanism of apoptosis induced by ziyuglycoside II. It is well known that the $\mathrm{Bcl}-2$ family of proteins constitutes an important control mechanism in the regulation of apoptosis $(16,18)$. Bcl-2 is an apoptosis inhibitor, and high Bcl-2 levels are required to maintain intracellular gene transfer and other changes required to block apoptosis. Bax is an apoptotic protein. It promotes apoptosis by competing with Bcl-2 in cells. Therefore, with a low level of Bax, induction of apoptosis may require upregulation of Bax expression. Thus, a change in the $\mathrm{Bax} / \mathrm{Bcl}-2$ ratio indicates the susceptibility of cells to apoptosis (19-21). According to our results, the $\mathrm{Bax} / \mathrm{Bcl}-2$ ratio increased in a dose-dependent manner compared with the control and redistribution of the Bax protein that occurred with ziyuglycoside II-induced apoptosis of BGC-823 cells. Caspase family proteases are downstream targets of
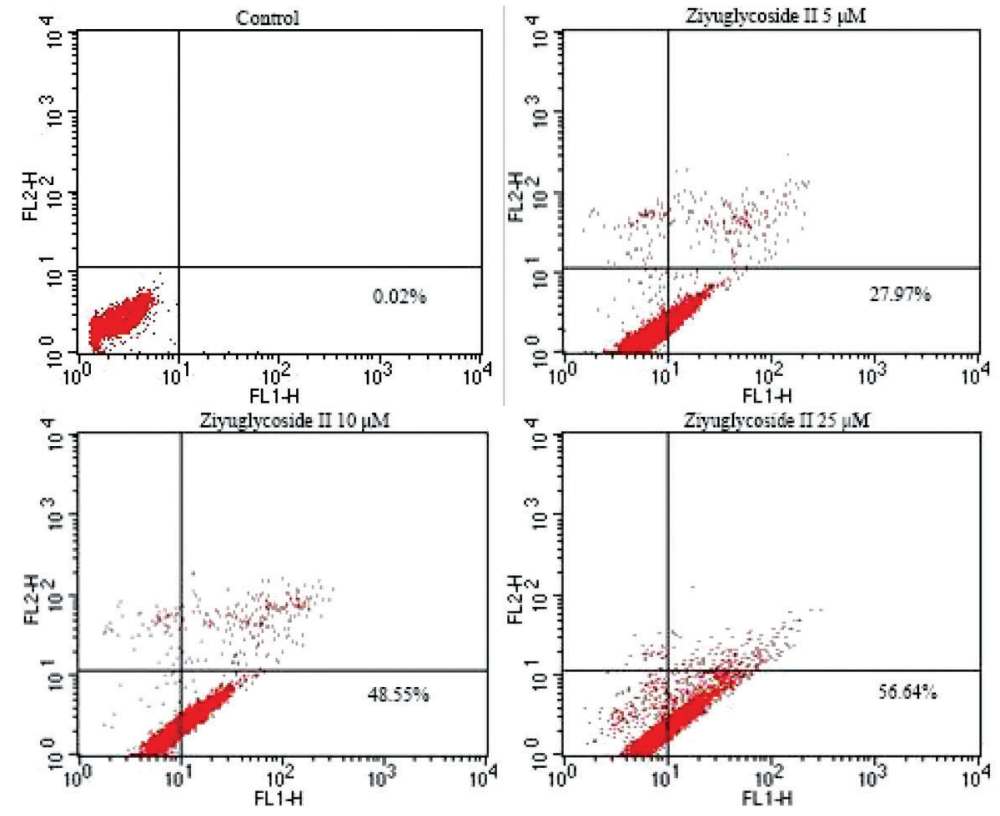

Figure 3. Effects of ziyuglycoside II on cell apoptosis in BGC-823 cells after a 24-h treatment. Cells were fixed and stained with Annexin V-FITC and propidium iodide $(\mathrm{PI})$ and then assessed by flow cytometry. Annexin $\mathrm{V}^{+} \mathrm{PI}^{-}$data are reported as percents of apoptotic cells. 
A

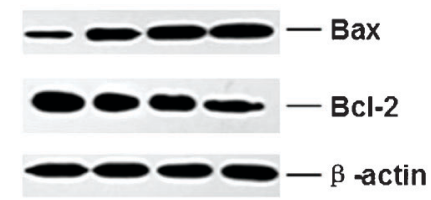

$0 \mu \mathrm{M} 5 \mu \mathrm{M} 10 \mu \mathrm{M} 25 \mu \mathrm{M}$

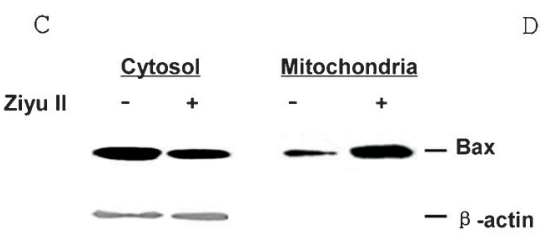

B
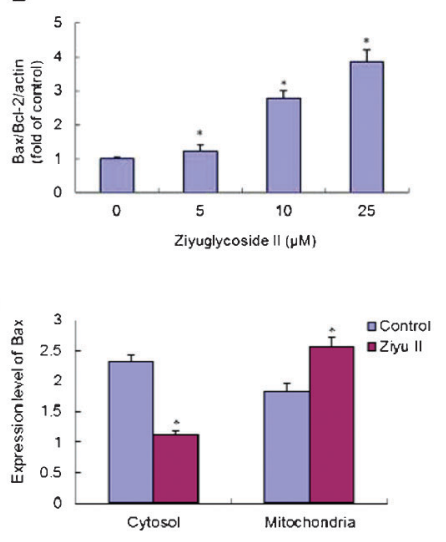

Figure 4. Effect of ziyuglycoside II on the expression of $\mathrm{Bax}$ and $\mathrm{Bcl}-2$ protein in BGC823 cells after a $24-\mathrm{h}$ treatment. $A$, Assessment of Bax and $\mathrm{Bcl}-2$ expression levels in BGC-823 cells by Western blotting. $B$, Effect of ziyuglycoside II on the ratio of values of $\mathrm{Bax} / \mathrm{Bcl}-2$. C, The subcellular expression level of the Bax protein in BGC-823 cells by Western blotting. $D$, Effect of ziyuglycoside II (Ziyu II) on subcellular distribution of Bax. Data are reported as means \pm SD for $\mathrm{n}=3 .{ }^{*} \mathrm{P}<0.05$ vs control (Student $t$-test).
Bax and $\mathrm{Bcl}-2$ in the mitochondrial apoptosis signaling pathway (22). The literature indicates that changes in the $\mathrm{Bax} / \mathrm{Bcl}-2$ ratio could regulate the activity of caspase proteins under in vitro and ex vivo conditions $(23,24)$. We examined the effects of caspase-1, $-3,-8$, and -9 inhibitors on inhibition of ziyuglycoside II-treated BGC-823 cell proliferation and found that the effect of ziyuglycoside II on BGC-823 cells was mediated by activating caspase- 3 activity. Although a direct role for caspase- 3 in stimulating tumor repopulation has not been described before, caspase-3 status could affect the tumor microenvironment in a significant way, which can also affect the outcome of tumor therapy. Our results clearly demonstrate that the activation of caspase- 3 was an important pathway of ziyuglycoside II-induced apoptosis of BGC823 cells.

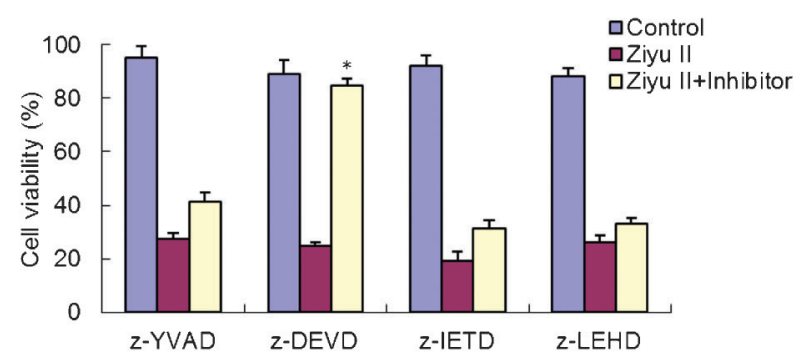

Figure 5. Effect of caspase inhibitors on ziyuglycoside II-induced BGC-823 cell apoptosis. Cells were pretreated with or without caspase inhibitor $(20 \mu \mathrm{M})$ for $1 \mathrm{~h}$ and then cultured with ziyuglycoside II (Ziyu II, $25 \mu \mathrm{M}$ ) for $12 \mathrm{~h}$. Caspase-1 inhibitor (z-YVAD-fmk: Z-Tyr-Val-Ala-Asp-fluoromethylketone), caspase-3 inhibitor (z-DEVD-fmk: z-Asp-Glu-Val-Asp-fluoromethylketone), caspase-8 inhibitor (z-IETD-fmk: z-Ile-Glu-Thr-Asp-fluoromethylketone), caspase- 9 inhibitor (z-LEHD-fmk: z-Leu$\mathrm{Glu}(\mathrm{OMe})$-His-Asp(OMe)-fluoromethylketone). After incubation, cell viability was assessed. Data are reported as means $\pm S D$ for $\mathrm{n}=3$ independent assays. ${ }^{*} \mathrm{P}<0.05$ vs ziyuglycoside II-treated (Student $t$-test).
We have demonstrated that ziyuglycoside II inhibited gastric carcinoma BGC-823 cell proliferation by inducing cell apoptosis but not cell cycle arrest. This effect was associated with the regulation of $\mathrm{Bax} / \mathrm{Bcl}-2$ expression and activation of caspase- 3 pathway. Therefore, our study contributed to better understanding of the antiproliferation effect of ziyuglycoside II as well as its underlying molecular mechanisms. This information will greatly assist in the future development of ziyuglycoside II as a potential anticancer agent to treat gastric carcinoma. Further studies will be required to evaluate the effects of ziyuglycoside II in ex vivo or in vivo situations.

\section{Acknowledgments}

Research supported by the Six Talent Peak Grant of Jiangsu Province (\#2011-wsk-103) and the Natural Science Foundation of Jiangsu Province (\#BK2011168, \#BK2012105).

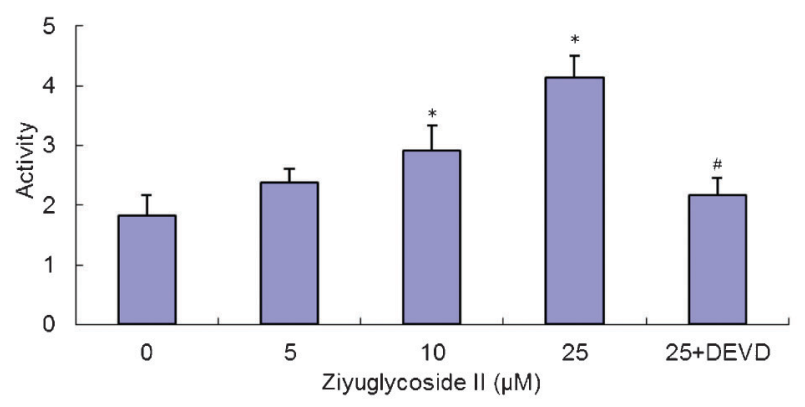

Figure 6. Activity of caspase-3 in ziyuglycoside II-induced BGC823 cell apoptosis. Cells were treated with the indicated drugs for 12 h. DEVD: caspase-3 inhibitor (z-DEVD-fmk: z-Asp-Glu-ValAsp-fluoromethylketone). After incubation, caspase-3 activity was determined by fluorimetric assay. Data are reported as means \pm SD for $\mathrm{n}=3$ independent assays. ${ }^{*} \mathrm{P}<0.05$ vs control, ${ }^{\#} \mathrm{P}<0.05$ vs ziyuglycoside II-treated (Student $t$-test). 


\section{References}

1. Yeoh KG. How do we improve outcomes for gastric cancer? J Gastroenterol Hepatol 2007; 22: 970-972, doi: 10.1111/j. 1440-1746.2007.04956.x.

2. Smyth EC, Cunningham D. Targeted therapy for gastric cancer. Curr Treat Options Oncol 2012; 13: 377-389, doi: 10.1007/s11864-012-0192-6.

3. Power DG, Kelsen DP, Shah MA. Advanced gastric cancer slow but steady progress. Cancer Treat Rev 2010; 36: 384392, doi: 10.1016/j.ctrv.2010.01.005.

4. Gill RS, Al-Adra DP, Nagendran J, Campbell S, Shi X, Haase $E$, et al. Treatment of gastric cancer with peritoneal carcinomatosis by cytoreductive surgery and HIPEC: a systematic review of survival, mortality, and morbidity. J Surg Oncol 2011; 104: 692-698, doi: 10.1002/jso.22017.

5. Zhang D, Fan D. Multidrug resistance in gastric cancer: recent research advances and ongoing therapeutic challenges. Expert Rev Anticancer Ther 2007; 7: 1369-1378, doi: $10.1586 / 14737140.7 .10 .1369$.

6. Zhang D, Fan D. New insights into the mechanisms of gastric cancer multidrug resistance and future perspectives. Future Oncol 2010; 6: 527-537, doi: 10.2217/fon.10.21.

7. Chen S, Flower A, Ritchie A, Liu J, Molassiotis A, Yu H, et al. Oral Chinese herbal medicine (CHM) as an adjuvant treatment during chemotherapy for non-small cell lung cancer: A systematic review. Lung Cancer 2010; 68: 137145, doi: 10.1016/j.lungcan.2009.11.008.

8. Wu T, Yang X, Zeng X, Eslick GD. Traditional Chinese medicinal herbs in the treatment of patients with esophageal cancer: a systematic review. Gastroenterol Clin North Am 2009; 38: 153-167, x, doi: 10.1016/j.gtc.2009.01.006.

9. Molassiotis A, Potrata B, Cheng KK. A systematic review of the effectiveness of Chinese herbal medication in symptom management and improvement of quality of life in adult cancer patients. Complement Ther Med 2009; 17: 92-120, doi: 10.1016/j.ctim.2008.11.002.

10. Lee NH, Lee MY, Lee JA, Jung DY, Seo CS, Kim JH, et al. Anti-asthmatic effect of Sanguisorba officinalis $\mathrm{L}$. and potential role of heme oxygenase- 1 in an ovalbumininduced murine asthma model. Int $\mathrm{J}$ Mol Med 2010; 26: 201-208.

11. Zhang S, Liu X, Zhang ZL, He L, Wang Z, Wang GS. Isolation and identification of the phenolic compounds from the roots of Sanguisorba officinalis L. and their antioxidant activities. Molecules 2012; 17: 13917-13922, doi: 10.3390/ molecules 171213917.

12. Choi ES, Kim JS, Kwon KH, Kim HS, Cho NP, Cho SD. Methanol extract of Sanguisorba officinalis L. with cytotoxic activity against PC3 human prostate cancer cells. Mol Med Rep 2012; 6: 670-674.

13. Cai Z, Li W, Wang H, Yan W, Zhou Y, Wang G, et al. Antitumor and immunomodulating activities of a polysaccharide from the root of Sanguisorba officinalis L. Int J Biol Macromol 2012; 51: 484-488, doi: 10.1016/j.ijbiomac.2012.05.029.

14. Wang Z, Loo WT, Wang N, Chow LW, Wang D, Han F, et al. Effect of Sanguisorba officinalis $L$ on breast cancer growth and angiogenesis. Expert Opin Ther Targets 2012; 16 (Suppl 1): S79-S89, doi: 10.1517/14728222.2011.642371.

15. Kim YH, Chung CB, Kim JG, Ko KI, Park SH, Kim JH, et al. Anti-wrinkle activity of ziyuglycoside I isolated from a Sanguisorba officinalis root extract and its application as a cosmeceutical ingredient. Biosci Biotechnol Biochem 2008; 72: 303-311, doi: 10.1271/bbb.70268.

16. Kirkin $\mathrm{V}$, Joos $\mathrm{S}$, Zornig $\mathrm{M}$. The role of Bcl-2 family members in tumorigenesis. Biochim Biophys Acta 2004; 1644: 229249, doi: 10.1016/j.bbamcr.2003.08.009.

17. Mishra BB, Tiwari VK. Natural products: an evolving role in future drug discovery. Eur J Med Chem 2011; 46: 47694807, doi: 10.1016/j.ejmech.2011.07.057.

18. Manion MK, Hockenbery DM. Targeting BCL-2-related proteins in cancer therapy. Cancer Biol Ther 2003; 2: S105-S114.

19. Jendrossek $\mathrm{V}$. The intrinsic apoptosis pathways as a target in anticancer therapy. Curr Pharm Biotechnol 2012; 13: 1426-1438, doi: 10.2174/138920112800784989.

20. Ott M, Norberg E, Zhivotovsky B, Orrenius S. Mitochondrial targeting of tBid/Bax: a role for the TOM complex? Cell Death Differ 2009; 16: 1075-1082, doi: 10.1038/cdd.2009.61.

21. Selvakumaran M, Lin HK, Miyashita T, Wang HG, Krajewski $\mathrm{S}$, Reed JC, et al. Immediate early up-regulation of bax expression by p53 but not TGF beta 1: a paradigm for distinct apoptotic pathways. Oncogene 1994; 9: 1791-1798.

22. Snigdha S, Smith ED, Prieto GA, Cotman CW. Caspase-3 activation as a bifurcation point between plasticity and cell death. Neurosci Bull 2012; 28: 14-24, doi: 10.1007/s12264012-1057-5.

23. Sawada M, Nakashima S, Banno Y, Yamakawa H, Hayashi $\mathrm{K}$, Takenaka $\mathrm{K}$, et al. Ordering of ceramide formation, caspase activation, and $\mathrm{Bax} / \mathrm{Bcl}-2$ expression during etoposide-induced apoptosis in C6 glioma cells. Cell Death Differ 2000; 7: 761-772, doi: 10.1038/sj.cdd.4400711.

24. Hoshyar R, Bathaie SZ, Sadeghizadeh M. Crocin triggers the apoptosis through increasing the $\mathrm{Bax} / \mathrm{Bcl}-2$ ratio and caspase activation in human gastric adenocarcinoma, AGS, cells. DNA Cell Biol 2013; 32: 50-57, doi: 10.1089/dna.2012.1866. 